Paideusis

\title{
Competition in Education (John Martin Rich and Joseph L. De
} Vitis)

\section{Ki Su Kim}

Volume 9, Number 2, 1996

URI: https://id.erudit.org/iderudit/1073245ar

DOI: https://doi.org/10.7202/1073245ar

See table of contents

Publisher(s)

Canadian Philosophy of Education Society

\section{ISSN}

0838-4517 (print)

1916-0348 (digital)

Explore this journal

Cite this review

Kim, K. (1996). Review of [Competition in Education (John Martin Rich and Joseph L. De Vitis)]. Paideusis, 9(2), 35-37. https://doi.org/10.7202/1073245ar viewed online.

https://apropos.erudit.org/en/users/policy-on-use/ 
The kind of practical knowledge which a teacher needs to acquire in order to teach well is, like knowing how to live well, the fruit of a person's experience and character. Like learning to live well, learning to teach well presupposes the integrity of teaching as a professional practice while also requiring advice in the course of a student-teacher's classroom experience from those who are already good teachers by virtue of being firmly disposed to exercise phronesis.

Given Dunne's emphasis on the significance to student-teachers of having the right kind of classroom experience with the right kind of mentors, one wonders about what sort of role educational studies can have in the education of teachers. Here, there is an important parallel with Aristotle's views about the role of the Nichomachean Ethics in the moral education of his audience. Although human beings do not become good simply by being given lectures in philosophy since they need the right sort of experience while growing up, nevertheless such lectures do contribute to the formation of a virtuous disposition by articulating, systematising, and defending the integrity of life within the Greek polis. In similar fashion, Dunne views educational studies as contributing to the development of those dispositions which are characteristic of good teachers by articulating, systematising, and defending the integrity of teaching as a practice. Back to the Rough Ground, although largely an interpretive work, makes its contribution to teacher education by articulating the significance of the techne-phronesis distinction to our understanding of teaching, while also defending the integrity of teaching by serving as a prophylactic against the virus known as the behavioural objectives model of teaching.

\section{Reviewed by Paul O'Leary, The University of Western Ontario}

\section{John Martin Rich and Joseph L. De Vitis, Competition in Education Springfield, Ill.: Charles C. Thomas, 1992. pp. 206 + viii}

The authors hold that "the roots of competition lie deep in American culture" and competition is "reflected and reinforced by educational institutions." From this viewpoint, they note educators' periodic recognition of the importance of competition in American education, and observe that competition's "full ramifications, significance, and danger have not been fully explored." This is an interesting observation for those for whom competition for survival has now become the day's imperative. What, then, are the ramifications, significance, and dangers? To put the conclusion first, the two hundred or so pages of the book do not supply a clear answer to these questions because the discussion is loose and not well organized. Though these questions are interesting, other matters are attended to such as "various major aspects of competition in education." Included are issues like "competition within educational policies, programs, and practices, as well as the problems certain forms of competition create," and "the influences on education of competitive values in American social and economic life." The ramifications of competition are largely omitted while various policies related to competition receive cursory and insufficiently elaborated comment.

The point of departure of their discussion is the claim that the roots of competition lie deep in American culture discussed in the section, "Competitive Ethic in American Culture." All that the reader sees is a quotation from Stanley 
Eitzen that competition is highly valued in American society, followed by the pronouncement that "that it is highly valued assures that it will be found in many institutions and organizations." The rest of the section is devoted to listing the areas in which competition is to be found: "the economy, the business world, the professions, politics, religion, the family, sports and athletics, courtship, and various types of organization." This kind of discussion may well lead to saying that "competitiveness pervades many aspects of American culture," but never that the roots of competition lie deep in American culture, or that there is a competitive ethic in that culture.

Surprisingly, then, the theme of competitive American culture appears to be forgotten in the rest of the book. Chapter Two ("Concepts of Competition") considers competition as a phenomenon of culture but in a way that is hardly comprehensible. While the discussion is based solely on Karl Mannheim's sociology of knowledge, it does not allow more than saying that competition is "a basic feature of social life." Even this assessment may be too generous because, strictly, Mannheimian sociology addresses the competition of interpretative positions regarding reality, not competition per se, nor the reality of human behaviour to which it may belong. Leaving the issue of competition as a cultural phenomenon, the authors tum to showing some cultures which anthropologists label as competitive or as co-operative. They conclude that "[s]ome ... cultures . . . are more extreme examples; other cultures may have more of a mixture of traits and behaviour patterns" because "[p]eople may behave toward others in ways that are neither co-operative nor competitive." At this point, the reader wonders why it should be held that the roots of competition lie deep in American culture or that there is a competitive ethic in that culture.

Their definition of competition-a "model" of competition which they present subsequently-is also troubling. They say there are three conditions for persons being in competition with one another: (i) two or more persons or groups strive for $\mathrm{R}$ (reward); (ii) $\mathrm{R}$ is in short supply, and only one or a limited number of persons can gain it, and (iii) the activities are rule governed. Simply put, this model is open to telling counter-examples. As well, it does not follow from the theme of competition as a cultural phenomenon or as something whose roots lie deep in American culture. Consider what rules should there be between two hungry, stray dogs which jump on to a piece of meat at the same time? Shall we say they do not compete since their activity does not involve rules? You may also consider the case where there is an attractive person in your neighbourhood and you are furtively seeking her favour. Suppose another man is doing the same thing without your knowledge. Are the two of you really in competition?

The author's discussions are notoriously incoherent and inconsistent. In Chapter Three, they propose to examine various social theories about the cultural phenomena, which have been constructed in light of whether human nature is competitive or co-operative. A disjointed discussion again leads to no substantive conclusion. After offering sketchy summaries of the "social theories" of Hobbes, social Darwinism, sociobiology, Freud, Adler, Piaget among others in a mere thirteen pages, the authors conclude that, at base, such theories "have not been conclusively warranted in either clinical or experimental studies in the social sciences." They also observe that "future theorists and practitioners in education and the social sciences would continue to make such assumptions about 'competitive' or 'co-operative' nature of human beings." 
They come to such simple conclusions without referring to any of the many empirical studies which a simple ERIC search would uncover in a matter of seconds.

The remaining chapters-namely, those on "Economic Models of Competition and Education" (Four), "The Glorification of Athletic Competition" (Five), "The Testing Movement in Education" (Six), "Meritocracy and Competition" (Seven), and even the bonus chapter on "Non-competitive Educational Programs and Practices" (Eight)-are not exceptional. Most of these chapters deal with theories, policies, and practices advocating, endorsing, condoning, or not supporting competition at all, rather than aspects of competition in the sense of persons or groups seeking scarce resources within given rules as the authors define the concept. Incoherence and inconsistency are visible through the chapters. Take, for example, the chapters on the testing movement and meritocracy. The testing movement may suggest allocation of scarce resources to candidates with highest scores. Meritocracy, as well, may imply the assignment of the best performers to important positions. Neither of these, however, requires such resources or positions to be given to the winners of a rule-governed competition. Too often, the best performers in a test are not necessarily the best rewarded. Meritocracy does not disallow what Canadians call "patronage" or appointing to important positions those persons whom you know personally although they are not the best performers. The indirect way of talking about competition via talking about the testing movement and meritocracy does not add very much to clarifying the "full ramifications, significance, and danger" of competition in education.

The result of such unorganized discussion is well represented in the way the book ends-that is, posing new questions rather than suggesting an answer to the question introduced at the outset. The new questions are: Is the competitive urge innate in human nature? Should competition be more greatly emphasized in American education in order to keep up internationally? Why do some cultures emphasize competition more than do others? And what are the prospects for creating sound educational programs based on competitive values?

Overall, it is unfair to call this a "bad"' book. Supplying a clear, coherent answer to the questions posed through consistent, solid discussions is a desirable condition for a "good" book, but it may not be a sine qua non. Picture books, for instance, may still be good if they supply a series of collated images with sensible annotations. The "various aspects of competition in education" (or, more strictly, various things related to competition in education) which the book deals with give an impression that it like such a picture book. The failure to meet the desirable condition is not unique to this book. Many works written to support or oppose the use of competition in education demonstrate similar shortcomings by simply listing competition's benefits and harms without full elaboration and argument. Meticulous conceptual analysis is often missing as is a careful examination of competition discourse itself. The merits of the book may be sought in this vein. Its "various aspects" approach suggests that many things are involved in the issue of competition in education. May one such thing not be the historical context in which we talk for or against competition?

Reviewed by Ki Su Kim, Memorial University 